\title{
FUZZY LOGIC IN THE SPATIAL AND TEMPORAL DISTRIBUTION IN THE QUALITY OF THE BEVERAGE IN CONILON COFFEE
}

\author{
Abel Souza da Fonseca ${ }^{1}$, Julião Soares de Souza Lima², Samuel de Assis Silva ${ }^{3}$, \\ Maria Christina Junger Delôgo Dardengo ${ }^{4}$, Alexandre Candido Xavier ${ }^{5}$
}

(Received: March 07, 2019; accepted: April 15, 2019)

\begin{abstract}
The objective in this study was to evaluate the spatial and temporal variability of the beverage quality by applying the fuzzy classification in the final global sensory analysis, for Coffea canephora Pierre ex A. Froehner, in two consecutive harvests. The studied variables were: fragrance (aroma), flavor, bitterness (sweetness), set, balance, cleaning, aftertaste, mouth feel, uniformity, salinity (acidity) and drink (global note). To the average overall scores of the drinks obtained on the cup-tasting at 80.0 points of a sampling, the mesh has applied the function of association of the fuzzy classification linear model to determine the degree of pertinence. The data were analyzed by the descriptive statistics and then by geostatistics to verify the existence and quantify the degree of spatial dependence of the variables. In the interval classified as "very good coffee" is found in the global average grade, in the two harvests. The methodology fuzzy applied in the global beverage note of the coffee conilon seminal made it possible to determine their spatial variability in the same distribution pattern in the two harvests, close ranges, and adjustments to the spherical model, which was confirmed by the spatial correlation of $61.6 \%$ among the fuzzy maps for the global score.
\end{abstract}

Index terms: Quality coffee, sensory analysis, cup-tasting, Coffea Canephora.

\section{LÓGICA FUZZY NA DISTRIBUIÇÃO ESPACIAL E TEMPORAL NA QUALIDADE DA BEBIDA DE CAFÉ CONILON}

\begin{abstract}
RESUMO: Objetivou-se com este trabalho avaliar a variabilidade espacial e temporal da qualidade da bebida aplicando-se a classificação fuzzy nas notas globais finais da análise sensorial, para Coffea canephora Pierre ex A. Froehner, em duas safras consecutivas. As variáveis estudadas foram: fragrância (aroma), sabor, amargor (doçura), conjunto, equilíbrio, limpeza, retrogosto, sensação, uniformidade, salinidade (acidez) e bebida (nota global). Aos resultados médios das notas globais das bebidas obtidas na prova de xícara nos 80,0 pontos de uma malha amostral aplicou-se a função de associação da classificação fuzzy linear para determinação do grau de pertinência. Os dados foram analisados pela estatística descritiva e em seguida pela geoestatística para verificar a existência e quantificar o grau de dependência espacial das variáveis. A nota global média encontra-se no intervalo classificado como "café muito bom", nas duas safras. A metodologia fuzzy aplicada na nota global da bebida do café conilon seminal possibilitou determinar a sua variabilidade espacial na lavoura com mesmo padrão de distribuição nas duas safras, alcances próximos e ajustes ao modelo esférico, o que foi confirmado pela correlação espacial de $61,6 \%$ entre os mapas fuzzy ficados para a nota global.
\end{abstract}

Termos para indexação: Café de qualidade, análise sensorial, prova de xícara, Coffea canephora.

\section{INTRODUCTION}

Demand for the market in consuming better quality coffee is driving farmers to improve production processes in order to achieve higher results on the final global drink score in the hedonic scale.

The conilon coffee (Coffea canephora Pierre ex A. Froehner) has sensorial characteristics in the quality of the drink, which normally present neutrality as to the sweetness, acidity and aroma of roasted cereals, being distinguished by the body more pronounced than the Arabica coffee (RIBEIRO et al. 2014). Due to the particularities of the taste and smell sensitivity for this variety the protocol was defined by the Coffee Quality Institute (CQI) (2010) to mark its sensorial analysis.

Schmidt and Miglioranza (2010) state that sensory analysis is an indispensable tool for the food industry and has different methods (discriminative, descriptive and effective) used by accredited tasters. For Schiano, Harwood, and Drake (2017) the evaluation of the sensorial characteristics of food products is the best method to characterize its quality. For these authors, the sensorial quality is an evaluation that consists of a series of tests or tooling applied in the definition of procedures in the definition of the quality of the product. For Thomazini et al. (2011) the quality

\footnotetext{
${ }^{1}$ Mepes Escola Família Agrícola de Ibitirama - Comunidade São Jose do Caparaó, S/N - 29.540-000 - Ibitirama - ES abelsouzafonseca@gmail.com

2,3,5Universidade Federal do Espírito Santo / UFES - Departamento de Engenharia Rural - Cx P. 16 - 29.500-000 - Alegre - ES

-limajss@yahoo.com.br, samuel.assilva@gmail.com, alexandre.candido.xavier.ufes@gmail.com

${ }^{4}$ Instituto Federal do Espírito Santo - Campus Alegre - 29.500-000 - Alegre - ES - mchrisjunger@hotmail.com
} 
of coffee can be defined as being the sum of all attributes that meet the needs of the consumer.

The sensorial analysis for coffee comes from the "cup-tasting" and the results obtained are presented in different classes for the quality of the beverage for both arabica and conilon coffee. Interpreting the results obtained by human sensitivity requires instruments that can translate the answers in a consistent way and with fewer uncertainties. Thus, studies are carried out to determine the correlation between the "cuptasting" with methods of chemical analysis of the roasted beans and with computational readers in the identification of the beverage standard. According to Schmidt and Miglioranza (2010), the results found by these computational readers have provided high correlations with the sensorial analysis.

Considering the uncertainties contained in the information, the fuzzy set has been used as an alternative in the interpretation of the results, since they are not limited to a deterministic value since the human perception about the quality of the food leads to different interpretations (LAZIM and SURIANI, 2009). This method aims to solve problems where information is not well defined and is based on the modeling of the problem and translates in mathematical terms the imprecise information contained in the natural language, expressed by linguistic variables that can be transformed (LIMA et al., 2018; SENTÜRK, 2017).

The spatial and temporal variability of soil attributes and those related to plants have been carried out in several studies considering the fuzzy classification (WANG et al., 2008; KIM et al., 2013, GHAEMI et al., 2014). As regards coffee, there is the application of fuzzy logic in several studies (FONSECA, JESUS, and LIMA, 2016, JESUS et al., 2016, LIMA et al., 2016). The spatial distribution of beverage quality in arabica coffee plantations was studied by Silva et al. (2015), and no variation was detected in the overall final note in relation to the distances between samples of coffee fruits harvested at the cherry stage, for the same post-harvest processing.

In this context, the objective in this work was to evaluate the spatial and temporal variability of the beverage quality by applying the fuzzy classification in the final global notes of the sensory analysis, for conilon coffee, in two consecutive harvests.

\section{MATERIAL AND METHODS}

The work was developed in the municipality of Cachoeiro de Itapemirim, in the Boa Vista community, São Vicente District. According to the climatic classification of Koppen-Geiger (1928), the region has CWA categorization. The soil of the area is classified as Cambisoil, sandy-clay texture, with the mean particle size fractions in the $0-0.20$ m layer, being: clay $=460\left(\mathrm{~g} \mathrm{~kg}^{-1}\right)$, silt $=90\left(\mathrm{~g} \mathrm{~kg}^{-1}\right)$ and total sand $=450\left(\mathrm{~g} \mathrm{~kg}^{-1}\right)$.

The plant species studied in the harvests of 2015/2016 (1) and 2016/2017 (2) was the coffee plant conilon (Coffea canephora Pierre ex A. Froehner) of seminal propagation, commercial cultivation, cultivated in spacing of $1.5 \times 1.5 \mathrm{~m}$ $\left(4,444\right.$ plants $\left.^{-1} \mathrm{a}^{-1}\right)$, located at latitude S $20^{\circ} 37^{\prime} 31$ "and longitude W $41^{\circ} 05^{\prime} 22^{\prime}$ ", at an altitude of $520 \mathrm{~m}$. The chemical management of the crop was according to the results of the soil chemical analysis, following recommendations of Prezotti et al. (2007), the cultural and phytosanitary treatments according to Ferrão et al. (2007).

The data of the average maximum and minimum temperatures and of the annual accumulated rainfall in harvests 1 and 2 were determined according to Xavier et al. (2015) and Drumond Neto (2017), respectively. In harvest 1 the average maximum temperature was 33.23 ${ }^{\circ} \mathrm{C}$ and the minimum was $15.8^{\circ} \mathrm{C}$ and annual cumulative rainfall of $820 \mathrm{~mm}$. In harvest 2 the maximum average temperature was $32.71{ }^{\circ} \mathrm{C}$ and a minimum of $14.72^{\circ} \mathrm{C}$, with cumulative annual rainfall of $1167 \mathrm{~mm}$.

In the experimental area was constructed a sample mesh of 80 random points marked with the total station, each point consisting of three plants. The nutritional status of the crops in harvests 1 and 2 was determined with leaves sampled in the third and fourth pair, from the end of the plagiotropic branch to the orthotropic branch, carried out in February of each harvest. The concentration of nutrients in foliar tissues by the Diagnosis and Recommendation Integrated System (DRIS) presented K (potassium) and B (boron) as the most limiting macro and micronutrients and the nutritional balance index (NBI) of 13.5 and 9.24 for harvests 1 and 2, respectively.

The architecture of the sample plants in the crops in harvests 1 and 2, respectively, was quantified with 5.0 and 3.0 orthotropic branches and 75.0 and 44.0 plagiotropic branches on average per plant. The average yields were 58.3 sc ha-1 (harvest 1) and $33.2 \mathrm{sc} \mathrm{ha}^{-1}$ (harvest 2), in a $60 \mathrm{~kg}$ bag. 
Harvesting was done by manual sifting in June, in both harvests, when the crop presented approximately $80 \%$ of the fruits in the cherry stage. From the total fruit mass harvested at each sampling point, 2 liters were removed, which were submerged in water to eliminate buoy coffee and other impurities. Afterward, the cherry fruits were selected manually and conditioned in bags of net. The samples were pre-dried in a covered suspended terrace, for a period of 24 hours, being revolved three times a day.

After this phase, the samples were taken to a laboratory oven with circulation and air renewal, at a temperature of $45^{\circ} \mathrm{C}\left( \pm 2^{\circ} \mathrm{C}\right)$, until the grains reached $11.5 \%$ b.u $( \pm 1 \%)$. The drying procedure was monitored daily with a digital water content meter for cereals. After drying, the samples were packed in paper bags and stored for 45 days in a sealed styrofoam box, protecting from environmental variations (SILVA et al., 2015). After the samples were harvested using an electric drive peeler with mechanical stripping process. A mass of $0.30 \mathrm{~kg}$ of raw grains of each sample was packed in silver metalized stand up pouch, these being intended for sensory analysis.

Sensory analysis "cup-tasting" was performed by a team of three specialized "R-Grades" tasters certified by the Coffee Quality Institute (CQI). Thus, the sensorial analyzes of the coffees were prepared and evaluated blindly by means of the cup-tasting according to the methodology of the coffee tasting protocol $C$. canephora (ICO, 2010).

The variables reported in the "cup-tasting", according to protocol, for the flat grains retained in the 13/64-inch sieve, are: fragrance (aroma), flavor, bitterness (sweetness), set, balance, cleanliness, aftertaste, sensation, uniformity, salinity (acidity) and drink (Global Note - GN). To these variables, a descriptive analysis was carried out to determine the position and dispersion measures (mean, median, minimum value, the maximum value and standard deviation) and the coefficients of asymmetry, kurtosis, and variation. The normality of the data was tested by the Kolmogorov-Smirnov test $(\mathrm{p}$-value $=0.05)$. Student's t-test $(\mathrm{p}$-value $=$ 0.05 ) was used to evaluate if the mean values of the variables between the two consecutive harvests presented a significant difference.

The average results of the global notes (GN) of the beverages obtained in the "cup-tasting" in the 80 sample points the fuzzy index $(F)$ was used to determine the degree of membership
(Fuzzy Index $=$ IF) for the overall results $(\mathrm{GN})$ of the drinks obtained in the "cup-tasting" in the 80.0 sample points, according to Silva and Lima (2009), Souza et al. (2009) and Lima et al. (2018), as follows:

$$
\begin{array}{lr}
M F_{A}(Z)=0 & \text { se } z<p \\
M F_{A}(Z)=\left(\frac{1}{\alpha}\right) *(z-p) & \text { se } p \leq z<q \\
M F_{A}(Z)=1 & \text { se } z \geq q
\end{array}
$$

in which: $\mathrm{MF}_{\mathrm{A}}=$ degree of relevance of the element $\mathrm{Z}$ (drink) to the fuzzy set, $\mathrm{q}$ and $\mathrm{p}=$ higher and lower value of set A (conilon coffee), $\alpha=\mathrm{q}-\mathrm{p}$;

The values of $p$ and $q$ were defined according to the classification of the quality of the beverage according to the tasting protocol for coffee C. canephora second (CQI) (EQUIPE CONILON BRASIL, 2011), UCDA (2010) and ICO (2010). After the fuzzification of the results of the sensorial analysis, the intervals are between zero and one (crisp value), respectively, defining the degree of pertinence (GP) for each NG, as described by quality [very good coffee (VGC), fine coffee (FC) and exceptional coffee (EC)]. It should be noted that values of NG below the minimum limit assumed zero values (0.00) and above the upper limit assumed values equal to 1.00 .

The use of fuzzy logic to deal with this uncertainty of NG is highly desirable. This not only helps to model imprecision in a logical way but also provides a consistent justification of the area in the field where there is a greater possibility of obtaining a better coffee as a result of adopting improvements in handling, harvesting and processing practices of coffee.

Spatial analysis was performed to determine the degree of spatial dependence of the global note (GN) of the beverage after fuzzification, using theoretical semivariogram adjustments to the experimental data, based on the assumption of intrinsic stationarity (equation 04).

$$
\gamma(h)=\frac{1}{2 N(h)} \sum_{i=1}^{N(h)}\left[\left(Z_{1}\left(x_{i}\right)-Z_{2}\left(x_{i}+h\right)\right)^{2}\right]
$$

in which: $\gamma(\mathrm{h})=$ the estimated semivariance; $\mathrm{N}$ (h) $=$ the number of pairs of the studied attribute; and $\mathrm{Z}\left(\mathrm{x}_{\mathrm{i}}\right), \mathrm{Z}\left(\mathrm{x}_{\mathrm{i}}+\mathrm{h}\right)=$ the values of the attributes measured at position $x_{i}$ and $x_{i}+h$, separated by a vector $h$ (distance between samples). 
TABLE 1 - Classification of beverage quality for C. canephora.

\begin{tabular}{cc}
\hline Mean global score & Quality description \\
$90,0 \leq \mathrm{EC} \leq 100,0$ & Exceptional coffee (EC) \\
$80,0<\mathrm{FC}<90,0$ & Fine coffee (FC) \\
$70,0 \leq \mathrm{VGC} \leq 80,0$ & Very good coffee (VGC) \\
\hline
\end{tabular}

The choice of the best fit semivariogram model was based on the minimization of the sum of the squares of the residuals (SQR) and the coefficient of multiple determination $\left(\mathrm{R}^{2}\right)$. For the definitive choice, it was based on the correlation coefficient between the observed values and those estimated by the cross-validation ( $\mathrm{r}-\mathrm{vc}$ ) (LIMA et al., 2018). The adjusted semivariograms were scaled by the data variance in order to verify the spatial distribution pattern of the fuzzy drink GN (degree of pertinence) among the harvests.

The degree of spatial dependence (DSD) was considered by the relation $\left[\mathrm{C}_{0} /\left(\mathrm{C}_{0}+\mathrm{C}\right)\right]$ $* 100$, classified according to Cambardella et al. (1994).

With the confirmed spatial dependence, maps of the spatial distribution of degrees of pertinence (GP) (fuzzification) for the GN of the beverage within the respective classes of quality description were made for the two harvests, using the ordinary kriging interpolation method. To the generated maps the spatial correlation analysis was applied to quantify the degree of temporal correspondence of the GN, between the harvests.

\section{RESULTS AND DISCUSSION}

The results of the descriptive analysis of the variables that characterize the beverage quality of conilon coffee are presented in Table 2. The highest coefficient of variation (CV) was $6.12 \%$ for bitterness (sweetness), in the second harvest. Ferreira et al. (2016) when studying Arabica coffee varieties, obtained values of coefficients of variation $(\mathrm{CV})$ of less than $12 \%$ for all the variables of the sensorial analysis. This value was considered low and adequate for the statistic used in the classification of the beverage of the evaluated beverage. These results highlight the attunement between the tasters in their taste and olfactory sensitivities.

It is observed that the mean and median values of all the variables were close, characterizing asymmetry not very marked, since their values were close to zero. It is noted that $50 \%$ of the variables under study presented negative asymmetry. In turn, the kurtosis coefficient characterizes platykurtic distribution for $63.6 \%$ of the variables. Thus, the variables Set $^{1}$, Equilibrium ${ }^{1}$, Fragrance ${ }^{1}$ and Retrogosto ${ }^{2}$ presented leptokurtic distribution $(\mathrm{Ck}>0)$ and the other variables had a variation for platykurtic distribution $(\mathrm{Ck}>0)$. It should be noted that the low values of $\mathrm{Ck}$ and $\mathrm{Cs}$ show a small variation in the distribution of the variables in relation to the normal distribution, thus confirming the normality of all variables under study.

The average values of the tasting notes for the variables that characterize the quality of the beverage for conilon coffee are presented in Figure 1. According to El Halal (2008), the classification by "cup-tasting" is an important operation at the commercial level, since by means of it the quality of the coffee is determined, which will influence its price and its acceptance in the market. The overlap of the notes (Figure 1) indicates similarity in the mean for the variables under study.

The fragrance/aroma kept a note above 7.00 in the two harvests and was the attribute that had a higher note after the uniformity and cleanliness. The fragrance refers to the odor of coffee after it is ground and still dry and the aroma is the odor of coffee after adding water. The taste, as well as the other attributes, showed no significant difference between the two crops [7.00 ( $\left.{ }^{1}\right)$ and 6.99 (2)], showing that the conditions of the crop and the methods of the procedure were not sufficient to alter the quality of the beverage from one harvest to another. Thus, as the fragrance/aroma, the flavor suffers great influence of the roast, which in this case was used medium roasted. Roasting is one of the most important steps to produce a good quality coffee, generating consumer satisfaction (MORAIS et al., 2007 and CHALFOUN et al, 2013). For Scholz et al. (2011) the coffee roasting process has the main purpose of forming aroma and flavor of the coffee beverage.

The aftertaste had notes 6.84 and 6.89 in harvest 1 and 2, respectively. This attribute complements the evaluation of the coffee flavor and is the sensation that remains in the mouth after ingesting the beverage (consumers) or discarding the beverage (evaluators). 
TABLE 2 - Descriptive statistics of attributes of sensory analysis and global note of coffee conilon beverage in crop 1 and 2.

\begin{tabular}{|c|c|c|c|c|c|c|c|c|c|}
\hline Variáveis & Média & $\mathrm{Md}$ & Min & Max & $\mathrm{S}$ & $\mathrm{CV}$ & $\mathrm{Cs}$ & $\mathrm{Ck}$ & $\mathrm{KS}$ \\
\hline Bitter/Sweetness ${ }^{1}$ & 6.88 & 6.88 & 6.08 & 7.75 & 0.38 & 5.45 & 0.08 & -0.45 & ns \\
\hline Bitter/Sweetness ${ }^{2}$ & 6.90 & 7.00 & 6.00 & 7.75 & 0.42 & 6.12 & -0.27 & -0.71 & ns \\
\hline Set $^{1}$ & 6.97 & 7.00 & 6.00 & 7.92 & 0.36 & 5.24 & -0.20 & 0.08 & ns \\
\hline Set $^{2}$ & 6.92 & 7.00 & 6.00 & 7.75 & 0.40 & 5.71 & -0.10 & -0.71 & ns \\
\hline Balance $^{1}$ & 6.92 & 6.92 & 6.00 & 7.83 & 0.36 & 5.27 & -0.07 & 0.13 & ns \\
\hline Balance $^{2}$ & 6.86 & 6.88 & 6.00 & 7.75 & 0.39 & 5.74 & -0.03 & -0.50 & ns \\
\hline Fragrance/Aroma ${ }^{1}$ & 7.12 & 7.08 & 6.33 & 8.33 & 0.35 & 4.99 & 0.33 & 0.71 & ns \\
\hline Fragrance/Aroma ${ }^{2}$ & 7.07 & 7.00 & 6.00 & 8.13 & 0.40 & 5.61 & 0.15 & -0.17 & ns \\
\hline Cleanliness ${ }^{1}$ & 10.00 & 10.00 & 10.00 & 10.00 & 0.00 & 0.00 & - & - & ns \\
\hline Cleanliness $^{2}$ & 10.00 & 10.00 & 10.00 & 10.00 & 0.00 & 0.00 & - & - & ns \\
\hline Aftertaste $^{1}$ & 6.84 & 6.88 & 6.00 & 7.58 & 0.34 & 4.90 & -0.28 & -0.27 & ns \\
\hline Aftertaste $^{2}$ & 6.89 & 6.88 & 6.00 & 8.25 & 0.42 & 6.04 & 0.52 & 0.20 & ns \\
\hline Flavor $^{1}$ & 7.00 & 7.00 & 6.00 & 7.83 & 0.37 & 5.24 & -0.15 & -0.13 & ns \\
\hline Flavor $^{2}$ & 6.99 & 7.00 & 6.00 & 7.75 & 0.38 & 5.42 & 0.03 & -0.31 & ns \\
\hline Salinity/Acidity ${ }^{1}$ & 6.89 & 6.92 & 6.00 & 7.75 & 0.36 & 5.28 & 0.22 & -0.15 & ns \\
\hline Salinity/Acidity ${ }^{2}$ & 6.89 & 6.88 & 6.00 & 7.75 & 0.42 & 6.10 & 0.10 & -0.57 & ns \\
\hline Mouthfeel $^{1}$ & 6.97 & 7.00 & 6.17 & 8.00 & 0.39 & 5.64 & 0.05 & -0.26 & ns \\
\hline Mouthfeel $^{2}$ & 6.89 & 6.88 & 6.00 & 7.75 & 0.42 & 6.08 & -0.23 & -0.67 & ns \\
\hline Uniformity $^{1}$ & 10.00 & 10.00 & 10.00 & 10.00 & 0.00 & 0.00 & - & - & ns \\
\hline Uniformity $^{2}$ & 10.00 & 10.00 & 10.00 & 10.00 & 0.00 & 0.00 & - & - & ns \\
\hline Global Note $^{1}$ & 75.58 & 75.63 & 68.75 & 81.75 & 2.65 & 3.51 & -0.11 & -0.03 & ns \\
\hline Global Note ${ }^{2}$ & 75.37 & 75.44 & 68.00 & 81.88 & 2.95 & 3.91 & 0.01 & -0.50 & ns \\
\hline
\end{tabular}

M: mean; Md: median; s: standard deviation; CV: coefficient of variation; Cs: Coefficient of symmetry; Ck: kurtosis coefficient; ns: normal distribution by Kolmogorov-Smirnov test (KS) at 5\% probability.

Meanwhile, the mean salinity/acidity score remained unchanged in the two harvests $(6,89)$. The Salinity / Acidity ratio is the relative balance between the sensations created by salt, mainly due to higher levels of potassium in Robustas coffee, in contrast to the normally lower levels of organic acids, particularly citric acid (UCDA, 2010).

Bitterness/sweetness refers to the pleasant sweet taste, and its perception is the result of the presence of carbohydrates (SILVEIRA et al., 2016).. For this study, the sweetness remained the standard in the two harvests with values of 6.88 and 6.90. The sensation in the mouth is a combination of weight and texture, and the weight comes from the microfine fibrous particles that the beans absorb from the soil, and the texture comes from the oils extracted from the coffee particles suspended in the beverage.
The attribute Balance is an evaluation between the intensity of the combination of Taste, aftertaste, Sensation in the mouth and Bitterness (sweetness). It should be very intense without any dispersion of the balance of the drink (UCDA, 2010). The scores for this attribute were 6.92 for the two harvests (Figure 1).

Drying is an important factor in determining uniformity and cleanliness. When drying in terraces, it is recommended that the wetter the coffee, the lower the thickness of the layer, to accelerate the removal of water (FONSECA, 2015). In this research, the cleaning is justified with maximum value by the procedure of handling the samples and processing of the grains in the elimination of the bark and parchment of the grains. 


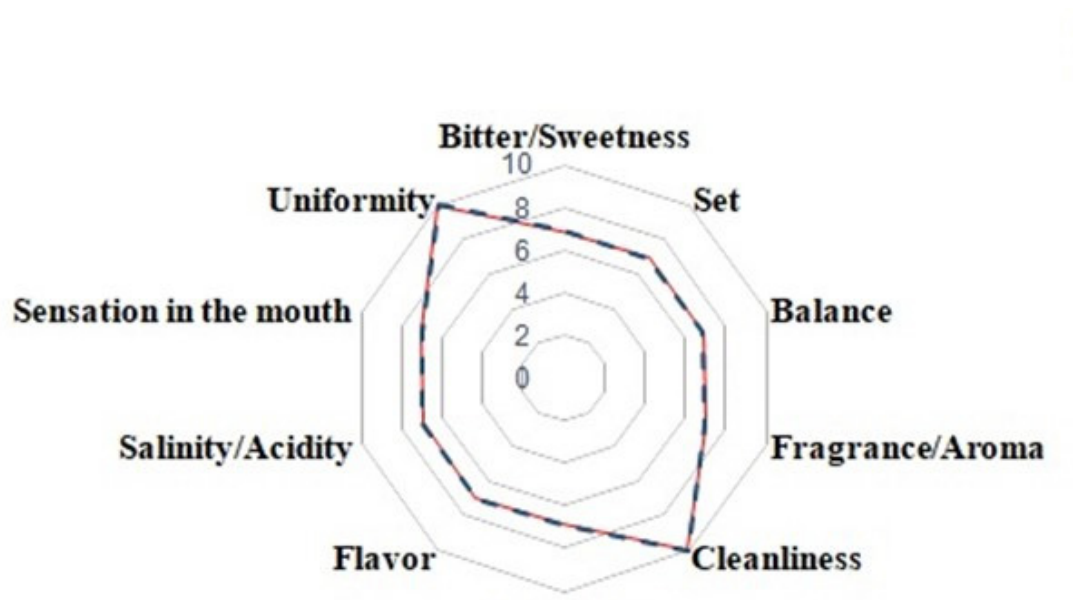

$\mathrm{GN}^{1}: 75,58$

$\mathrm{GN}^{2}: 75,37$

Aftertaste

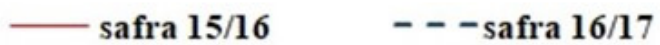

FIGURE 1 - Mean values of the attributes of the sensory analysis and global note (GN) of the conilon coffee beverage, in two harvests.

The set is the last attribute to be determined and the score is given according to the combination of all previous variables. In this regard, all harvesting and processing steps influence, since any process that disrupts one of the previous attributes will affect the combination of the final set. The greater the care in the steps to produce quality coffee the better the score of the evaluated set. The score for the combined attribute was 6.97 in the first crop and 6.92 in the second crop.

The scores of all the variables obtained were higher than those found by Galote et al. (2013). This is because in the cited work the harvest was carried out in a non-selective manner, manual sifting in the sieve, post-harvest processing by a dry process without separation of the fruits. The fruits were submitted to drying in a clay-cement terrace. This reveals the superiority in terms of punctuation when it is carried out the selection of cherry grains, carefully in the harvesting process, preparation of the samples of the conilon coffee fruits and the drying process. The climate conditions also promote the fermentation in the harvest period, processing and/or storage (ANGÉLICO et al., 2008; GEROMEL et al., 2006; NOBRE et al., 2011), resulting in a difference in comparative studies.

However, in this study, the climatic conditions presented few variations between the two harvests in the coffee phenological cycle.
In a study by Ferreira et al. (2016), the obtained scores for the variables evaluated following the protocol for arabica, also, were smaller than the attributes obtained for this study. In spite of being different species and protocols, the superiority of conilon coffee in relation to the study shows its capacity to be in the market as very good coffee (CMB), according to the classification for this species. It should be emphasized that the comparison of the beverage alone for arabica coffee and conilon coffee should be avoided for the same market since they have intrinsic characteristics that differentiate them. To seek out consumer markets that appreciate the characteristics of both coffees is more important than the beverage comparisons.

The final mean of the overall score (GN) was 75.58 in the first harvest and 75.37 in the second, with no significant difference by the t-test ( $p$-value $\leq 0.05$ ). In a study conducted by Drumond Neto (2017), in the same area of this research and the fruits processed through dry (natural coffee) yields GN of 76.0 in the harvest of 2014/2015, showing that in three harvests followed, maintained similarity in the NG of the beverage. The pattern of drinking in the three consecutive years is related to the altitude, peculiar climatic characteristics of the region, management (liming, fertilization and pruning) and a high percentage of ripe fruits (cherry) at the time of harvest, placing the crop in question in the coffee class very good (CMB). 
It is observed in these studies that conilon coffee has the potential to improve the quality of its beverage, which obtained a mean GN above 75.0. It should be noted that in the study carried out by Alves (2012) it was found for GN Arabica coffees of 72.0 for Catuai Amarelo, in the cerrado; Mundo Novo NG of 76,5 and Topázio 75,8 in the south of Minas Gerais.

Cortez (2004) and CETCAF (2012) state that brands of coffee marketed with $100 \%$ conilon have been obtaining great acceptance of the consumer market when all the harvesting and postharvest stages are carried out properly. According to Scholz et al., (2011) coffees grown at higher altitudes grain development is slower, resulting in larger size and increased sucrose and acidity of the beverage. It is known that coffee conilon is cultivated in Espirito Santo in larger areas at altitudes lower than $400.0 \mathrm{~m}$.

The amplitude between the maximum and minimum limits in the very good coffee range $(\mathrm{CMB})$ is 10 points $(70 \leq \mathrm{CMB} \leq 80)$, generating uncertainty as to the way these notes are distributed at the sampling points in the crop. The GN at the sampling points were in the classification of very good coffee $(\mathrm{CMB})(70.0 \leq \mathrm{CMB} \leq 80.0)$, in the two harvests. When applied to the fuzzy logic in the NG of the sensorial analysis, degrees of pertinence (DP) were obtained for each sampling point. Once this was done, the semivariograms were adjusted and the spatial variability results of the DP are shown in Table 3.

The theoretical semivariogram model that best fit the experimental data was the spherical one, with spatial dependence range of 15.0 and $13.0 \mathrm{~m}$ for harvests 1 and 2, respectively, showing the same pattern of spatial dependence. Samples separated by distances smaller than the range are correlated to each other, allowing interpolations to be performed for smaller spacings than that used in sampling (LIMA et al., 2009). According to Fonseca et al. (2015), the range is extremely important to evaluate the experiment since it indicates the distance from which the samples are independent, that is, it indicates that from this point the average value is an acceptable statistic to evaluate the experiment.

The nugget effect (CO) represents the unexplained variability and according to Lima et al. (2016), the lower the proportion of the nugget effect in relation to the semivariogram level, the greater the spatial dependence presented, which in this study presented GDE equal to $38.0 \%$ and $33.0 \%$ for harvests 1 and 2, respectively. This spatial dependence is considered moderate according to the classification of (CAMBARDELLA et al., 1994). These GDE values indicate how much of the spatial variance is contributing to the total variance of the data, being $59.0 \%$ and $71.0 \%$, respectively, in harvests 1 and 2 .

The higher the degree of pertinence found (NG of $80=$ GP of 1.0) nearer the upper limit are the $\mathrm{NG}$, and the note is close to the lower limit for the fine coffee (CF) class. In addition, one has an idea of how good the notes are within the preestablished range.

Considering the fuzzified values for GN of the beverage and the semivariogram adjustments the spatialization of degree of pertinence (DP), in the two harvests, in the spatial and temporal analysis is presented in Figure 2.

In both crops, most of the area presented a degree of relevance greater than 0.50 , as can be observed in the lighter colors that are present in the whole area. In this study, DP values above 0.50 showed notes greater than 75 points in the very good coffee class (CMB), characterizing most of the crop.

When comparing the maps of the spatial distribution of the $\mathrm{PD}$, regarding form, there is a correlation in the temporal variability of the drink between the harvests. The sensorial analysis relevance of the 2015/2016 harvest and the 2016/2017 harvest season presented significant spatial correlation with $\mathrm{r}=61.6 \%$ (Figure 3). As NG (GP) increases within the area in the 2015/2016 harvest, similar performance also occurs in the 2016/2017 harvest, that is, the plants produce fruits that present similar NGs between the harvests.

As the majority of the samples were in the range of very good coffee (CMB), having 1 point with GN less than or equal to 70 and 4 greater or equal to 80 in the harvest 1 and $3 \mathrm{NG}$ smaller or equal to 70 and 6 greater or equal to 80 in crop 2, the application of fuzzy logic decreased the loss of information by the ability to obtain GP. The success in the use of fuzzy logic corroborates the results presented by Lanzillotti and Lanzillotti (1999) who studied the application of fuzzy logic in decision making in the sensorial analysis as an alternative to evaluate food and food preparations. The fuzzy logic was also efficient in sensory analysis of bread in a study carried out by Cavalcanti et al. (2013).

It can be seen in Figure 3 that the fuzzy maps for NG in harvests 1 and 2 show asymmetric distribution on the left and right, respectively. 
TABLE 3 - Models and parameters of the semivariograms staggered for the conilon coffee beverage, in two harvests.

\begin{tabular}{ccccccc}
\hline & Model & $\mathrm{C}_{0}$ & $\mathrm{C}_{0}+\mathrm{C}$ & $\mathrm{a}(\mathrm{m})$ & $\mathrm{GDE}(\%)$ & $\mathrm{R}^{2}(\%)$ \\
\hline GP Harvest 1 & ESF & 0,36 & 0,95 & 15,0 & 38,0 & 50,0 \\
GP Harvest 2 & ESF & 0,35 & 1,06 & 13,0 & 33,0 & 47,0 \\
\hline
\end{tabular}

GP2016: degree of pertinence for harvest 1 and GP2017: degree of pertinence for harvest 2

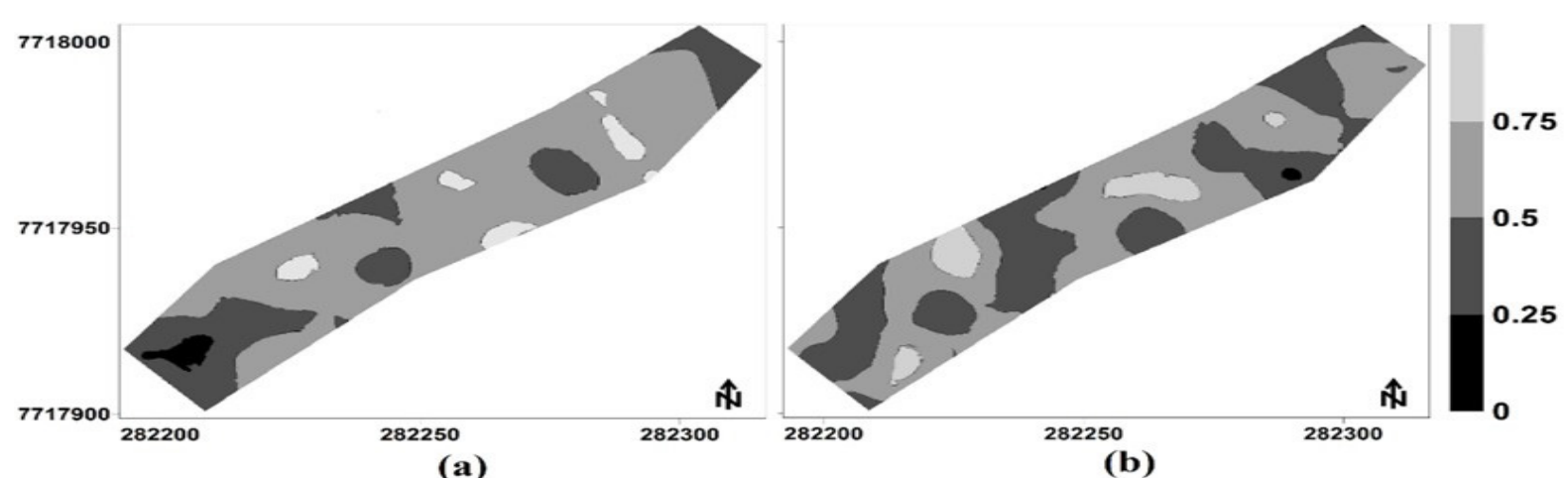

FIGURE 2 - Maps of the spatial distribution of the degree of pertinence (DP) for the coffee conilon beverage, in the harvests of 2015/2016 (a) and 2016/2017 (b).
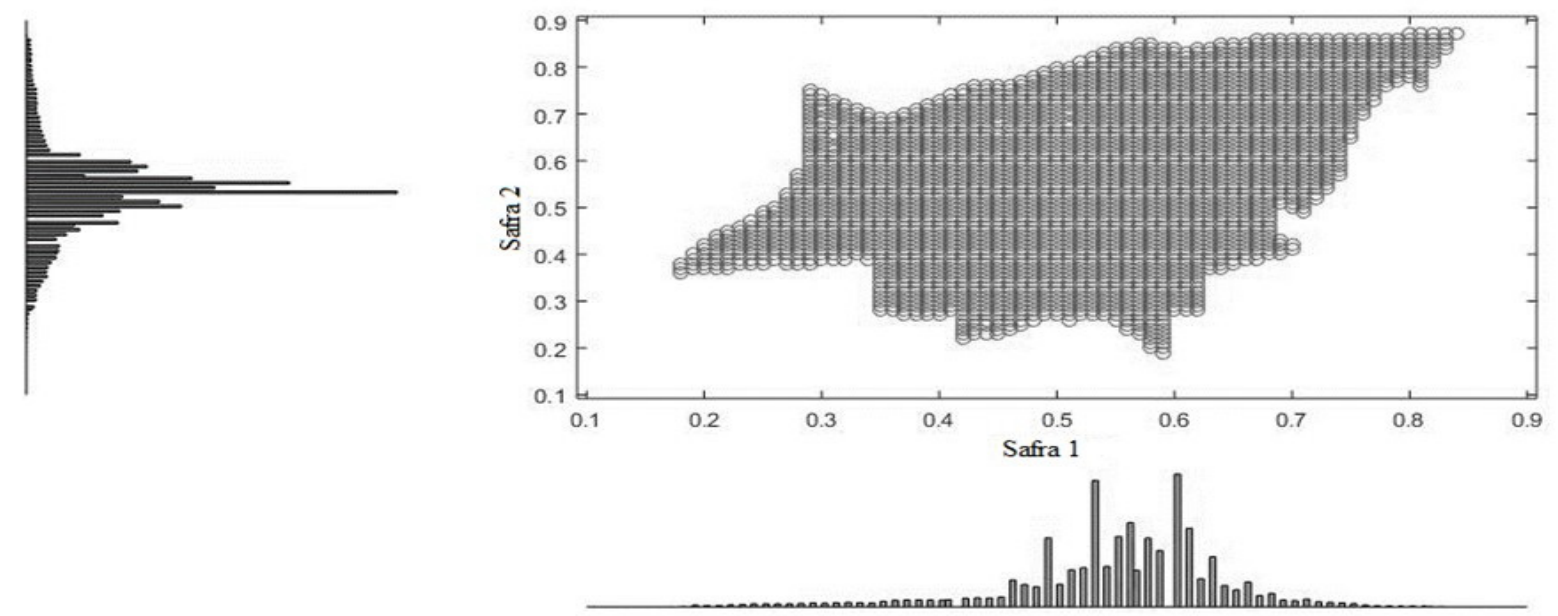

FIGURE 3 - Map of the spatial correlation of degrees of pertinence (DP) for conilon coffee beverage in harvests 1 and $2(2015 / 2016$ and 2016/2017).

\section{CONCLUSIONS}

The average global score $(\mathrm{GN})$ from the beverage of seminal propagation conilon coffee is in the range classified as "very good coffee" $(\mathrm{CMB})$ in the two harvests.

There was no significant temporal variation between the mean of the global scores (GN) and the variables that characterize the quality of the drink in the sensory analysis ("cup-tasting").

The fuzzy methodology applied in the global note $(\mathrm{GN})$ of the beverage of the seminal conilon coffee fruits allowed determine its spatial variability in the same distribution pattern in the two harvests, with a spatial-temporal correlation of $61.6 \%$. 


\section{ACKNOWLEDGMENTS}

The authors wish to thank CNPq and FAPES for the financial resources made available to carry out this research.

\section{REFERENCES}

ALVES, B. H. P. (2012). Análise Química do Aroma e da Bebida de Cafés de Minas Gerais e Espírito Santo em Diferentes Graus de torra.Tese. Universidade Federal de Uberlândia, 2012. 162f.

ANGÉLICO, C. L. et al. Diferentes estádios de maturação e tempos de ensacamento sobre a qualidade do café. Coffee science, v.6, n.1, p. 8-19, 2011.

CAMBARDELLA, C. A. et al. Fiel-Scale Variability of soil properties in Central Iowa Soils. Soil Science Society of America Journal., v. 58, p. 1501-1511, 1994

CAVALCANTI, M. T.; et al.. Aplicação da lógica fuzzy na análise sensorial de pão de forma enriquecido de pão de forma enriquecidos. Revista Brasileira de Engenharia Agrícola e Ambiental, v. 17, n. 2, p. 208 215, 2013.

CETCAF - CENTRO DE DESENVOLVIMENTO TECNOLÓGICO DO CAFÉ. Estudo de qualidade dos diferentes tipos de café conilon produzidos no ES. 2012. Disponível em: <http://www.cetcaf.com.br/padrao\%20 bebida\%20conilon/projeto\%20padraobebidaco nilon. $\mathrm{htm}>$. Acces on: 25 oct. 2017.

CHALFOUN, S. M. et al. Sensorial characteristics of coffee (Coffea arabica L.) VARIETIES IN THE ALTO PARANAÍBA REGION. Coffee Science, v. 8, n. 1, p. 43-52, 2013.

COFFEE QUALITY INSTITUTE (CQI). Fine Robusta Coffee Standards and Protocols. Available in: Acces on: 20 nov. 2017.

CORTEZ, J. G. Padrões de bebida para café conilon. In: SIMPÓSIO ESTADUAL DE CAFÉ, 6., 2004, Vitória, ES. Anais... Vitória, ES: 2004.

DRUMOND NETO, A. P. (2017) Qualidade física e sensorial de grãos de Coffea canephora Pierre Ex. Froehner de diferentes ambientes. Tese. Universidade Federal do Espirito Santo, 2017. 77f.
EL HALAL, S. L. M. Composição, processamento e qualidade do café. 2008. 46f. Trabalho acadêmico Universidade Federal de Pelotas, Pelotas. EMBRAPA. Histórico. 2009. Disponível em: <http://www22.sede. embrapa.br/cafe/unidade/historico.htm>. Acess on: 25 oct. 2017.

EQUIPE CONILON BRASIL. Novo protocolo de degustação de robustas é testado: Cafés capixabas obtiveram resultados animadores. Revista Conilon Brasil. Vitória, ES. v.8, p10-11. 2011.

FERRÃO, R. G. et al. Café conilon. Vitória, ES: Incaper, 702p. 2007

FERREIRA, W. P. M. et al..Effects of the Orientation of the Mountainside, Altitude and Varieties on the Quality of the Coffee Beverage from the "Matas de Minas" Region, Brazilian Southeast. American Journal of Plant Sciences, v.7, p. 1291-1303. 2016

FONSECA, A. S.; JESUS, M. L.; LIMA, J.S.S. Lógica fuzzy na análise espacial dos teores de $\mathrm{K}$ e $\mathrm{S}$ no tecido foliar do mamoeiro. Revista Univap, v. 22, n. 40, p. 730, 2016.

FONSECA, A. S. et al. Spatial variability of the productivity and the nutritional condition of coffee canephora. Coffee Sicence, v.10, p.420-428, 2015

GALOTE, J. K. B. et al. Índices de qualidade e bebida dos frutos do conilon robusta tropical por via seca. Enciclopédia Biosfera, v. 9, n. 17, p. 1647-1653, 2013.

GEROMEL, C. et al. Biochemical and genomic analysis of sucrose metabolism during coffee (Coffea arabica) fruit development. Journal of Experimental Botany, 2006. v. 57, n. 12, p. 3243-3258.

GHAEMI, M. et al. Spatio-temporal soil quality assessment under crop rotation irrigated with treated urban wastewater using fuzzy modelling. International Agrophysics, v. 28, n. 3, p. 291-302, 2014.

ICO, I. C. O. Protocolo para Degustação de Robusta Fino. Uganda, África: [s.n.], 2010.

JESUS, M. L. et al. Lógica fuzzy na análise espacial dos teores de boro e manganês no tecido foliar do cafeeiro conilon. Revista Univap, v. 22, n. 40, p. 240, 2016.

KIM, M; INAKAZU, T; KOIZUMI, A; KOO, J; Statistical approach for corrosion prediction under fuzzy soil environment. Environmental Engineering Research, v. 18, n. 1, p. 37-43, 2013. 
KÖPPEN, W.; GEIGER, R. Klimate der Erde. Gotha: Verlag Justus Perthes. 1928. Wall-map $150 \mathrm{~cm} \times 200 \mathrm{~cm}$.

LANZILLOTTI, R. S.; LANZILLOTTI, H. S. Análise sensorial sob o enfoque da decisão fuzzy. Revista de Nutrição, v.12, p.145- 157, 1999.

LAZIM M. A.; SURIANI, M. Sensory evaluation of the selected coffee products using fuzzy approach. World Academy of Science, Engineering and Technoly International Journal of Mathematical and Computational Sciences, v. 50, n.2. p.133-136, 2009.

LIMA, J. S. S. et al. Fuzzy Classification in the Determination of Input Application Zones. Revista Brasileira de Ciência do Solo, v.40, p.1-15, 2016.

LIMA, J. S. S. at a.l. Variabilidade espacial da textura de um Argissolo Vermelho Amarelo sob cultivo de pastagem e vegetação nativa. Ciência Rural, v. 399399, p. 2634-2637, 2009.

LIMA, J. S. et al. Fuzzy logic and geostatistics in studying the fertility of soil cultivated with the rubber tree. Revista Ciência Agronômica, v. 49, n. 2, p. 228238,2018

MORAIS, SAL. et al.Análise química de café arábica (Coffea arabica 1.) e grãos pretos, verdes e ardidos (pva) submetidos a diferentes graus de torração. Coffee Science, vol: 2 (2) pp: 97-11, 2007.

NOBRE, G. W. et al. Composição química de frutos imaturos de café arábica (Coffea arabica L.) processados por via seca e via úmida. Coffee Science, 6(2), 107-113, 2011

PREZOTTI, L. C. et al. (ed.). Manual de recomendações de calagem e adubação para o Estado do Espírito Santo - 5a Aproximação. Vitória, ES. SEEA/INCAPER/CEDAGRO. 305p, 2007.

RIBEIRO, B. B. et al. Avaliação química e sensorial de blends de Coffea canephora Pierre e Coffea arabica L. Coffee Science, Lavras, v. 9, n. 2, p. 178-186, 2014.

SCHIANO, A.N. HARWOOD, W.S. DRAKE, M.A. A. 100-Year Review: Sensory analysis of Milk. Journal of Dairy Science, v. 100, n.12, p. 9966-9986, 2017.
SCHMIDT, C. A. P.; MIGLIORANZA, E. Análise sensorial e o café: uma revisão. Revista Científica Inovação e Tecnologia, v. 01, n.02. p. 16-24. 2010.

SCHOLZ, M. B. S.; et al. Características físicoquímicas de grãos verdes e torrados de cultivares de café (Coffea arabica L.) do IAPAR. Coffee science, 6(3); 245-255, 2011.

SENTÜRK, S. Construction of fuzzy c control charts based on fuzzy rule method. Anadolu University Journal of Science and Technology, v.18, n.3, p. 563 $-572,2017$.

SILVA, S. A. et al. Mapping the potential beverage quality of coffee produced in the Zona da Mata, Minas Gerais , Brazil. Journal of the Science of Food and Agriculture, v. 96, p. 3098-3108, 2015.

SILVA, S. A; LIMA, J. S. S. Lógica fuzzy no mapeamento de variáveis indicadoras de fertilidade do solo. IDESIA, v. 27, n. 3, p. 41- 46, 2009.

SILVEIRA, A. S. et al. Sensory analysis of specialty coffee from different environmental conditions in the region of Matas de Minas, Minas Gerais, Brazil. Revista Ceres, 63(4), 436-443. 2016.

SOUZA, G. S. et al.. Aplicação de lógica fuzzy e geoestatística na análise da fertilidade de um solo sob pastagem. Revista Ciência Agronômica, v. 40, n. 3, p. 323-330, 2009.

THOMAZINI, A. et al. Abordagem sobre qualidade da bebida no café conilon. Enciclopédia Biosfera, v. 7, n. 12, p. 1-16, 2011.

UCDA - Uganda Cofee Development Authority. Protocolos para degustação do Robusta, Junho de 2010. Disponivel em: <http://www.ico.org/documents/pscb123-p-robusta.pdf>. Acesso em 01 jan. 2017.

WANG, Q. et al. Soil depth spatial prediction by fuzzy soil-landscape model. J Soils Sediments v.18, p.10411051, 2018.

XAVIER, A. C.; KING, C. W.; SCANLON, B. R. Daily gridded meteorological variables in Brazil (19802013), International Journal of Climatology, v.36, n.6, p.2644-2659, 2016. 